\title{
Evaluation of Hepatitis B Surface Antibody and Specific Gamma Interferon Response in Health Care Workers After Vaccination
}

\author{
Mohammad Hosein Sarmast Shooshtari ${ }^{1,2}$; Manoochehr Makvandi ${ }^{1,3,4}$; Mojtaba Rasti ${ }^{3, *}$; \\ Niloofar Neisi ${ }^{1,3}$; Nasrin Rastegarvand ${ }^{3}$; Amir Pouremamali ${ }^{3}$; Mehrdad Sadeghi Haj ${ }^{3}$; Far- \\ din Ghaedi ${ }^{5}$ \\ ${ }^{1}$ Research Institute for Infectious Diseases of Digestive System, Ahvaz Jundishapur University of Medical Sciences, Ahvaz, IR Iran \\ ${ }^{2}$ Department of General Surgery, School of Medicine, Ahvaz Jundishapur University of Medical Sciences, Ahvaz, IR Iran \\ ${ }_{3}$ Virology Department, School of Medicine, Ahvaz Jundishapur University of Medical Sciences, Ahvaz, IR Iran \\ ${ }^{4}$ Health Research Institute, Infectious and Tropical Disease Research Center, Ahvaz Jundishapur University of Medical Sciences, Ahvaz, IR Iran \\ ${ }^{5}$ Deputy of Public Health, Ahvaz Jundishapur University of Medical Sciences, Ahvaz, IR Iran \\ ${ }^{*}$ Corresponding author: Mojtaba Rasti, Virology Department, School of Medicine, Ahvaz Jundishapur University of Medical Sciences, Ahvaz, IR Iran. Tel: +98-6113354389, Fax: +98- \\ 6113361544, E-mail: mojtabarasti@yahoo.com \\ Received: July 25, 2013; Revised: September 24, 2013; Accepted: October 6, 2013
}

\begin{abstract}
Background: Health care workers are at high risk of acquiring hepatitis B virus (HBV) infection through occupational exposure to blood or body fluids. Thus, the assessment of anti-HBs status after immunization is very important.

Objectives: This study aimed to evaluate the measurement of HBsAb titer and specific gamma interferon response among the vaccinated health care workers in Golestan Hospital, Ahvaz, Iran.

Patients and Methods: The blood samples of 39 health care workers, including13 general surgeons, 10 anesthesiologists, 5 neurosurgeons, 3 general physicians, 1 orthopedist, 2 urologist and 5 nurses were collected during June 2013. All the participants had received HBV vaccine. They had received last vaccine dose from 2 months to 14 years ago. Their sera were tested for anti-hepatitis B antibody and HBc-IgG by the ELISA. Also, the evaluation of specific interferon $\gamma$ response against HBsAg was carried out using ELISA test. The age of health care workers were between 24 and 58 years with the mean age of $34.3 \pm 7.4 \mathrm{y}$.

Results: Out of 39 sera, 22 (56.41\%) had HBsAb titer above $100 \mathrm{IU} / \mathrm{mL}, 17$ (43.6\%) had titer below $100 \mathrm{IU} / \mathrm{mL}, 27$ (69.2\%) had positive specific HBsAg interferon $\gamma, 8(20.5 \%)$ cases had positive antibody response above 100IU, but negative for specific interferon $\gamma$ and $3(7.6 \%)$ cases were positive for HBc-IgG.

Conclusions: Overall, $87.2 \%$ of the health care workers had immunity against HBV infection, which showed remarkable immunity response following HBV vaccination. Booster dose of HBV vaccine is recommended for those whose immunity are below $100 \mathrm{IU} / \mathrm{mL}$.
\end{abstract}

Keywords:Hepatitis B Virus; Interferon Gamma; Workers

\section{Background}

Hepatitis B virus (HBV) belongs to family Hepadnaviridae and is a DNA virus. HBV causes acute and chronic liver disease. Although HBV vaccine is currently used, HBV infection remains one of the 10 most common causes of the death worldwide. About 400 million of the world population is infected with HBV, and around 250,000 people die each year from HBV related liver disease such as cirrhosis and hepatocellular carcinoma (1). A high prevalence of HBV infection was reported in Iran (2).

Healthcare workers are exposed to blood and body fluids. They are also at risk of incidents like needle stick, sharp injuries, and the like that could make the transmission of HBV infection easy through health care workers (3). The risk of acquiring hepatitis B infection among the health care workers is about 10 times higher than other groups (4). The HBs antibody has an important role in the protection against HBV infection (5). The expression of antiviral, Th1 cytokines such as gamma interferon (IFN- $\gamma$ ) and tumor necrosis factor- $\alpha$ (TNF- $\alpha$ ) can control hepatitis $B$ infection (6). Hepatitis B vaccine can motivate the immune system to produce both HBsAb and specific HBs gamma interferon (7). Immunization with hepatitis $B$ vaccine at first day, 30th day, and 180th day can create 90\% and $95 \%$ protection in adults and children, respectively (8). Antibody protection for general population is found at the titer of $>10 \mathrm{mIU} / \mathrm{mL}(9,10)$. Persons with anti-HBs titer $<10 \mathrm{mIU} / \mathrm{mL}$ are defined as non-responder, and persons with anti-HBs titer $>10$ and $<99 \mathrm{mIU} / \mathrm{mL}$ are defined as hyporesponders. They usually show shorter period of detectable antibody called "waning antibody" or "waning immunity" (11,12).

\section{Objectives}

The HBV vaccination program was started in Iran since 1989. This study aimed to evaluate the titer of HBsAb

Copyright (c) 2015, Ahvaz Jundishapur University of Medical Sciences. This is an open-access article distributed under the terms of the Creative Commons Attribution-NonCommercial 4.0 International License (http://creativecommons.org/licenses/by-nc/4.0/) which permits copy and redistribute the material just in noncommercial usages, provided the original work is properly cited. 
among the vaccinated health care workers of the Golestan Hospital in Ahvaz, Iran.

\section{Patients and Methods}

This cross-sectional study was carried out on 39 health care workers, including 13 general surgeons, 10 anesthesiologists, 5 neurosurgeons, 3 general physicians, 1 orthopedist, 2 urologists, and 5 nurses from Golestan Hospital in Ahvaz, during 2013. Among them, 24 (61.5\%) were males and $15(38.4 \%)$ were females. The health care worker's age ranged from 24 to 58 years with the mean age of $34.3 \pm 7.4$ $\mathrm{y}$. Then, They grouped based on their HBsAb titer: $<10,11-$ 100 , and $>100 \mathrm{mIU} / \mathrm{mL}$. Another classification was done based on cases with antibody titer lower than $10 \mathrm{mIU} /$ $\mathrm{mL}$ and higher than $10 \mathrm{mIU} / \mathrm{mL}$ for doing more statistical analysis. Based on our findings, HBsAb titer was lower than $10 \mathrm{mIU} / \mathrm{mL}$ in $12.8 \%$ (5) of participants. It was between 11 and $100 \mathrm{mIU} / \mathrm{mL}$ in $30.8 \%$ (12) of them. And finally, the titer was higher than 100 in $56.4 \%$ (22) of cases. Vaccination history of health care workers and their antibody titer were showed in Table 1 . All the health care workers had history of the needle stick injuries for several times.

\subsection{Enzyme-Linked Immunosorbant Assay for Hep- atitis B Antibody Titration}

Initially, a 5-ml blood sample was taken from each healthcare worker in a glass tube containing EDTA. After centrifugation, the plasma was collected and tested for the titer of anti-HBsAb and detection of HBc-IgG, using ELISA kit (Diapro, Italy) according to the manufacturer's instruction.

\subsection{Preparation of Peripheral Blood Mononuclear Cells}

Peripheral blood mononuclear cells were isolated from fresh blood supplemented with EDTA by Ficoll-Hypaque (Baharafshan, Iran) density gradient centrifugation. Briefly, $5 \mathrm{ml}$ blood sample was added to a glass tube containing $2 \mathrm{ml}$ Ficoll followed by centrifugation for 20 minutes at $2500 \mathrm{rpm}$. Then, the cell plate was suspended in RPMI medium and washed three times. One hundred and seven mononuclear cells of each health care worker was resuspended in RPMI 1,640 medium, supplemented with $2 \mathrm{mmol} / \mathrm{L}$ l-glutamine, $1 \mathrm{mmol} / \mathrm{L}$ sodium pyruvate,
$100 \mathrm{U} / \mathrm{mL}$ penicillin, $100 \mathrm{U} / \mathrm{mL}$ streptomycin, and $2.5 \mu \mathrm{g}$ amphotericin B. Next, $2.5 \mu \mathrm{g}$ purified recombinant HBs vaccine was added to each well containing 107 mononuclear cells. The plate was incubated at $5 \% \mathrm{CO} 2$ for 72 hours. Culture's supernatant was aspirated and the concentration of interferon $\gamma$ was measured by human interferon $\gamma$ ELISA test kit (eBioscience, Vienna, Austria) according to manufacturer's instructions. An informed consent was taken from each health care worker participated in this study. The study was approved by Ethics Committee of Ahvaz Jundishapur University of Medical Sciences.

\subsection{Statistical Analysis}

The statistical analysis was performed using SPSS (Version 19) software. Chi-Square test was done and P value of $<0.05$ was considered statistically significant.

\section{Results}

Out of 39 health care workers, 24 (61.5\%) were male and 15 (38.4\%) were female. The health care worker's age was between 24 and 58 years with the mean age of $34.3 \pm 7.4$ years. None of the health care workers were smoker; they were not overweight and did not have chronic liver disease, lung, or kidney disease. About 28 (80\%) health care workers had received three doses of vaccine or more (Table 2). On the basis of HBsAb titer, the health care workers were divided into 3 groups. Group 1 had HBsAb titer below 10 IU. Group 2 had HBsAb titer between 10 and 100 IU and group 3 had HBsAb titer above 100 IU. About 34 (87.2\%) health care workers showed HBsAb response to the vaccine as higher than $10 \mathrm{mIU} / \mathrm{mL}$. Twenty-two (56.4\%) health care workers who had received last dose of vaccine $6.6 \pm 4.3$ years ago had titer of HBsAb higher than 100IU/ ml. Seventeen (43.6\%) subjects who had received last dose of vaccine $10 \pm 4.06$ years ago, showed HBs titers lower than 100 IU and $3(7.7 \%)$ health care workers were positive for HBc-IgG and HBsAb but negative for interferon $\gamma$.

Tables 3 and 4 show the measurement and distribution of HBsAb and interferon $\gamma$ among the health care workers in different age groups. Table 3 indicates that first group had better response to vaccine (OR: 3.11) compared to other age groups. The mean of $18.9 \pm 36.5 \mathrm{pg} /$ $\mu \mathrm{L}$ of the specific interferon $\gamma$ response was observed in the age group (30-39) that was higher than other age groups. Twenty-seven (69.2\%) health care workers had

\begin{tabular}{|c|c|c|c|c|c|c|c|c|}
\hline \multirow[t]{2}{*}{ Elapsed time from vaccination } & \multicolumn{2}{|c|}{ HBsAb Titer, mIU/mL } & \multirow{2}{*}{$\begin{array}{c}\text { Odds Ratio (95\% } \\
\text { CI })\end{array}$} & \multirow[t]{2}{*}{ PValue } & \multicolumn{3}{|c|}{ HBs Ab Titer, mIU/mL } & \multirow[t]{2}{*}{ PValue } \\
\hline & $0-10$ & $>10$ & & & 0-10 & 11-100 & $>100$ & \\
\hline$<5$ years & $1(10)$ & $9(90)$ & $1.222,(0.098-15.230)$ & 0.876 & $1(10)$ & $1(10)$ & $8(80)$ & 0.273 \\
\hline 5-10 years & $1(6.7)$ & $14(93.3)$ & $0.607,(0.050-7.415)$ & 0.694 & $1(6.7)$ & $4(26.7)$ & $10(66.7)$ & 0.854 \\
\hline$>10$ years & $1(11.1)$ & $8(88.9)$ & $1.438,(0.114-18.076)$ & 0.778 & $1(11.1)$ & $5(55.6)$ & $3(33.3)$ & 0.104 \\
\hline Total & $3(8.8)$ & $31(91.2)$ & - & 0.922 & $3(8.8)$ & $10(29.4)$ & $21(61.8)$ & 0.255 \\
\hline
\end{tabular}

\footnotetext{
a Data are presented as No.(\%).
} 
Sarmast Shooshtari MH et al.

positive specific interferon $\gamma$ response against HBV vaccine, while 12 (30.8\%) cases were negative for specific $\gamma$ in- terferon (Table 4). Antibody and interferon responses in males and females were shown in Table 5.

\begin{tabular}{|c|c|c|c|c|c|c|c|c|c|}
\hline \multirow[t]{2}{*}{ Vaccination } & \multicolumn{2}{|c|}{ HBsAb Titer, mIU/mL } & \multirow[t]{2}{*}{ Odds Ratio (95\% CI) } & \multirow[t]{2}{*}{ P Value } & \multicolumn{4}{|c|}{ Vaccination Dose } & \multirow[t]{2}{*}{ P Value } \\
\hline & $0-10$ & $>10$ & & & 1 Dose & 2 Doses & 3 Doses & Upper & \\
\hline Complete & $3(10.3)$ & $26(89.7)$ & $0.897,(0.792-10.015)$ & 0.410 & - & - & $25(89.3)$ & $3(10.7)$ & 0.000 \\
\hline Incomplete & $0(0)$ & $6(100)$ & $0.897,(0.792-10.015)$ & 0.410 & $1(14.3)$ & $6(85.7)$ & - & - & 0.000 \\
\hline Total & $3(8.6)$ & $32(91.4)$ & 0.897, (0.792-10.015) & 0.410 & $1(2.9)$ & $6(17.1)$ & $25(71.4)$ & $3(8.6)$ & 0.000 \\
\hline
\end{tabular}

a Data are presented as No. (\%).

Table 3. Measurement and Distribution of HBsAb in Different Age Groups ${ }^{\mathrm{a}}$

\begin{tabular}{|c|c|c|c|c|c|c|c|c|}
\hline \multirow[t]{2}{*}{ Age Group, y } & \multicolumn{3}{|c|}{ HBsAb Titer, mIU/mL } & \multirow[t]{2}{*}{ PValue } & \multicolumn{2}{|c|}{ HBsAb Titer, mIU/mL } & \multirow[t]{2}{*}{ Odds Ratio (95\% CI) } & \multirow[t]{2}{*}{ PValue } \\
\hline & 0-10 & 11-100 & $>100$ & & 0-10 & $>10$ & & \\
\hline 20-29 & $2(25)$ & $3(37.5)$ & $3(37.5)$ & 0.377 & $2(25)$ & $6(75)$ & $3.11(0.423-22.866)$ & 0.248 \\
\hline $30-39$ & $3(13.6)$ & $5(22.7)$ & $14(63.6)$ & 0.460 & $3(13.6)$ & $19(86.4)$ & $1.184,(0.175-8.021)$ & 0.862 \\
\hline 40-49 & $0(0)$ & $4(50)$ & $4(50)$ & 0.276 & $0(0)$ & $8(100)$ & $1.192,(1.022-1.391)$ & 0.224 \\
\hline $50 \geq$ & $0(0)$ & $0(0)$ & $1(100)$ & 0.673 & $0(0)$ & $1(100)$ & $1.152,(1.0172-1.303)$ & 0.698 \\
\hline Total & $5(12.8)$ & $12(30.8)$ & $22(56.4)$ & 0.538 & $5(12.8)$ & $34(87.2)$ & - & 0.494 \\
\hline
\end{tabular}

a Data are presented as No. (\%)

Table 4. Interferon Response in Different Age Groups a

\begin{tabular}{|c|c|c|c|}
\hline Age Group, y & Interferon, $\mathbf{p g} / \mu \mathbf{L}$ & Number of cases, No. (\%) & PValue \\
\hline 20-29 & $8.2 \pm 7.9,(0-22)$ & $8(21.1)$ & 0.636 \\
\hline $30-39$ & $18.9 \pm 36.5,(0-167)$ & $22(57.9)$ & 0.670 \\
\hline $40-49$ & $16.2 \pm 27.3,(0-91)$ & $8(21.1)$ & 0.432 \\
\hline $50 \geq$ & - & $0(0)$ & No Statistic is Computed \\
\hline Total & $16.1 \pm 30.3,(0-167)$ & $38(100)$ & 0.621 \\
\hline
\end{tabular}

${ }^{\mathrm{a}}$ Data are presented as No. (\%).

Table 5. Antibody and Interferon Response Based on Gender a

\begin{tabular}{|c|c|c|c|c|c|c|c|c|c|c|}
\hline \multirow[t]{2}{*}{ Gender } & \multicolumn{2}{|c|}{ HBsAb Titer, mIU/mL } & \multirow[t]{2}{*}{ Odds Ratio (95\% CI) } & \multirow[t]{2}{*}{ PValue } & \multicolumn{3}{|c|}{ HBsAb Titer, mIU/mL } & \multirow[t]{2}{*}{ PValue } & \multirow[t]{2}{*}{ Interferon $\mathrm{pg} / \mu \mathrm{L}$} & \multirow[t]{2}{*}{ PValue } \\
\hline & 0-10 & $>10$ & & & 0-10 & 11- 100 & $>100$ & & & \\
\hline Male & $2(8.3)$ & $22(91.7)$ & $0.364,(0.053-2.487)$ & 0.289 & $2(8.3)$ & $9(37.5)$ & $13(54.2)$ & 0.376 & $24(63.2)$ & 0.449 \\
\hline Female & $3(20)$ & $12(80)$ & $0.364,(0.053-2.487)$ & 0.289 & $3(20)$ & $3(20)$ & $9(60)$ & 0.376 & $14(36.8)$ & 0.449 \\
\hline Total & $5(12.8)$ & $34(87.2)$ & $0.364,(0.053-2.487)$ & 0.289 & $5(12.8)$ & $12(30.8)$ & $22(56.4)$ & 0.376 & $38(100)$ & 0.449 \\
\hline
\end{tabular}

${ }^{\mathrm{a}}$ Data are presented as No. (\%).

\section{Discussion}

The risk of acquiring hepatitis B virus (HBV) infection is high among health care workers (HCWs) because of their much exposure to blood or its products. There are few reports about HBV prevalence in health care workers in Iran. One study reported that $23 \%$ of the health care workers of National Iranian Oil Company had exposure to HBV infection (13). This report suggests that injection of hepatitis B immunoglobulin should be mandatory in those health care workers who had negative HBsAb. Based on reports, about $13 \%$ to $60 \%$ of individuals who have received first $\mathrm{HBV}$ vaccine may lose antibody against hepatitis B virus later (in years) (10). It seems that a boost- 
er HBV vaccine could be useful for those health care workers that recognized as hyporesponders (immunity lower than $100 \mathrm{IU} / \mathrm{mL}$ ).

In Iran, some studies showed the persistence of hepatitis B antibody (anti-HBs) in $47 \%-80 \%$ of people who received the last dose of vaccine 10-16 years ago (14-16). In this study, the age group (20-29 years) shows better antibody response(OR:3.11) compared to other groups, which is similar to previous reports $(12,17)$. The age group (30 to 39) shows better gamma interferon response to HBV vaccine, although 12 (30.7\%) health care workers were negative for gamma interferon, which is consistent with the findings of Lu et al. study (18). There was no significant difference in the rate of high anti-HBs titer $(>100 \mathrm{IU} / \mathrm{mL})$ between females and males ( $\mathrm{P}>0.05)$; however, some studies reported that females show better response to HBV vaccine than males (12). We found that in $87.1 \%$ of individuals who received $\mathrm{HBV}$ vaccine, $\mathrm{HBs} A \mathrm{~b}$ titer is higher than $10 \mathrm{mIU} / \mathrm{ml}$, which is similar to report of Bahmani et al. (17) and Saberifiroozi et al. (19).

Twenty-seven (69.2\%) health care workers had positive specific interferon $\gamma$ response against HBV vaccine. Interferon $\gamma$ plays an important role in the prevention of $\mathrm{HBV}$ infection in the presence of low titer of HBsAb (18). Previous reports have shown that increase in interferon $\gamma$ expression in coordination with CD8 and CD4 T cell will help to complete virus clearance (20). Other studies suggest that increase in interferon $\gamma$ concentration will decrease serum hepatitis B viral load. It means that hepatitis B viral load and interferon $\gamma$ level have negative correlation (21). In this study, 12 (30.7\%) health care workers were negative for interferon $\gamma$. Only 2 (5.1\%) of them received last dose of $\mathrm{HBV}$ vaccine about two years ago, however they had high titer of HBsAb.

It is estimated that about $5 \%$ to $7 \%$ of the population are nonresponsive to vaccine. It could be due to a sort of defectiveness in specific $\mathrm{T}$ or B cell generation, expression of some kind of leukocyte antigens (HLA), degradation of $B$ cells by cytotoxic $T$ cell, tolerance or even imbalance in T-helper cells $(12,22)$. Some of HLA antigens like DR7 DR3 and DQ2 have negative effects on vaccination outcome and cytokine secretion like interferon $\gamma$ (23). In our study, HLA antigens of health care workers were not investigated, but it could be a reason for decrease in interferon $\gamma$ concentration in some cases. In our study, 3 (7.7\%) cases were positive for anti $\mathrm{HBc}$, which indicates the presence of the past HBV infection. Bahmani et al. (17) reported that $6.4 \%$ of the health care workers had positive HBc-IgG. All three cases were surgeons, probably because of their occupation, which is a risk factor for HBV infection. These three cases could be candidates for occult hepatitis B infection. However, occult HBV infection requires further investigation.

\section{Acknowledgements}

This study was done as a research project (registration number 9101) in Research Institute for Infectious Diseas- es of Digestive System, Ahvaz Jundishapur University of Medical Sciences, Ahvaz, Iran. We thank the chief and personnel of the Research Institute for approval and financial support of the study. We should also be grateful to Dr Arti and Dr Eftekhar as the chief of Golestan Hospital and faculty of dentistry and their colleagues for their collaboration in this study.

\section{Authors' Contributions}

Mr Mohammad Hosein Sarmast Shooshtari: obtaining funding for the study; Mr Manoochehr Makvandi: study, design and manuscript correction; Mr Mojtaba Rasti: manuscript preparation, doing experiment, and sample collection; Mrs Niloofar Neisi, Miss Nasrin Rastegarvand, and Mr Amir Pouremamali: doing experiment and sample collection; Mr Mehrdad Sadeghi Haj: statistical Analysis; and Mr. Fardin Ghaedi: manuscript preparation.

\section{Funding/Support}

This study was supported by Research Institute for Infectious Diseases of Digestive System in Ahvaz University of Medical Science.

\section{References}

1. Mizukoshi E, Sidney J, Livingston B, Ghany M, Hoofnagle JH, Sette A, et al. Cellular immune responses to the hepatitis B virus polymerase. JImmunol. 2004;173(9):5863-71.

2. Alavian SM, Mahboobi N, Mahboobi N. Anti-HBs antibody status and some of its associated factors in dental health care workers in Tehran University of Medical Sciences: Anti-HBs Ab and associated factors in dental society. Hepat Mon. 2011;11(2):99-102.

3. Di Giuseppe G, Nobile CG, Marinelli P, Angelillo IF. A survey of knowledge, attitudes, and behavior of Italian dentists toward immunization. Vaccine. 2007;25(9):1669-75.

4. Mahoney FJ, Stewart K, Hu H, Coleman P, Alter MJ. Progress toward the elimination of hepatitis B virus transmission among health care workers in the United States. Arch Intern Med. 1997;157(22):2601-5.

5. Wang J, Gujar SA, Cova L, Michalak TI. Bicistronic woodchuck hepatitis virus core and gamma interferon DNA vaccine can protect from hepatitis but does not elicit sterilizing antiviral immunity. JVirol. 2007;81(2):903-16.

6. Guidotti LG, Ishikawa T, Hobbs MV, Matzke B, Schreiber R, Chisari $\mathrm{FV}$. Intracellular inactivation of the hepatitis B virus by cytotoxic T lymphocytes. Immunity. 1996;4(1):25-36.

7. Mancini-Bourgine M, Fontaine H, Brechot C, Pol S, Michel ML. Immunogenicity of a hepatitis B DNA vaccine administered to chronic HBV carriers. Vaccine. 2006;24(21):4482-9.

8. Mast E, Mahoney F, Kane M, Margolis H. Hepatitis B vaccine. In: Plotkin SA, Orenstein W. A. editors. Vaccines.. Philadelphia: WBSaunders; 2004. p. 299 -337.

9. Poland GA, Jacobson RM. Clinical practice: prevention of hepatitis B with the hepatitis B vaccine. NEngl J Med.2004;351(27):28328.

10. Hepatitis B virus: a comprehensive strategy for eliminating transmission in the United States through universal childhood vaccination. Recommendations of the Immunization Practices Advisory Committee (ACIP). MMWR Recomm Rep. 1991;40(RR13):1-25.

11. Poland GA. Hepatitis B immunization in health care workers. Dealing with vaccine nonresponse. Am J Prev Med.1998;15(1):73-7.

12. Sjogren MH. Prevention of hepatitis B in nonresponders to initial hepatitis B virus vaccination. Am J Med. 2005;118 Suppl 10A:34S-9S.

13. Hamidi B, Bahadori M, Mansouri S, Nategh R. Seroepidemiologi 
cal survey of hepatitis B markers in National Iranian Oil Company (NIOC) health workers in Tehran prior to mass vaccination. Arch Irn Med. 2000;3:1-5.

14. Jafarzadeh A, Montazerifar SJ. Persistence of anti-HBs antibody and immunological memory in children vaccinated with hepatitis B vaccine at birth.J Ayub Med Coll Abbottabad. 2006;18(4):4-9.

15. Jafarzadeh A, Zarei S, Shokri F. Low dose revaccination induces robust protective anti-HBs antibody response in the majority of healthy non-responder neonates. Vaccine. 2008;26(2):269-76.

16. Alavian SM, Mansouri S, Abouzari M, Assari S, Bonab MS, Miri SM. Long-term efficacy of hepatitis B vaccination in healthcare workers of Oil Company Hospital, Tehran, Iran (1989-2005). Eur J Gastroenterol Hepatol. 2008;20(2):131-4

17. Bahmani MK, Khosravi A, Mobasser A, Ghezelsofla E. Seroprevalence of hepatitis B virus infection and vaccination compliance among health care workers in Fars Province, Iran. Arch Clin Infect Dis. 2010;5(1):45-50.

18. Lu CY, Ni YH, Chiang BL, Chen PJ, Chang MH, Chang LY, et al. Humoral and cellular immune responses to a hepatitis $\mathrm{B}$ vaccine booster 15-18 years after neonatal immunization. J Infect Dis. 2008;197(10):1419-26.

19. Saberifiroozi M, Gholamzadeh S, Serati AR. The long-term immunity among health care workers vaccinated against hepatitis $B$ virus in a large referral hospital in southern Iran. Arch Iran Med. 2006;9(3):204-7.

20. Bertoletti A, Tan AT, Gehring AJ. HBV-Specific Adaptive Immunity. Viruses. 2009;1(2):91-103.

21. Dimitropoulou D, Karakantza M, Theodorou GL, Leonidou L, Assimakopoulos SF, Mouzaki A, et al. Serum cytokine profile in patients with hepatitis $B$ e antigen-negative chronic active hepatitis B and inactive hepatitis B virus carriers. World J Gastrointest Pathophysiol. 2013;4(1):24-7.

22. Kardar GA, Jeddi-Tehrani M, Shokri F. Diminished Th1 and Th2 cytokine production in healthy adult nonresponders to recombinant hepatitis B vaccine. Scand J Immunol. 2002;55(3):311-4.

23. Jafarzadeh A, Shokri F. TH1 and TH2 responses are influenced by HLA antigens in healthy neonates vaccinated with recombinant hepatitis B vaccine. Iran JAllergy Asthma Immunol. 2012;11(4):308-15. 